\title{
Betanodavirus infection in primary neuron cultures from sole
}

\author{
Sandra Souto * (10, José G. Olveira, Lucía Vázquez-Salgado, Carlos P. Dopazo and Isabel Bandín
}

\begin{abstract}
Nervous necrosis virus (NNV), G. Betanodavirus, is the causative agent of viral encephalopathy and retinopathy, a disease that causes mass mortalities in a wide range of fish species. Betanodaviruses are neurotropic viruses and their replication in the susceptible fish species seems to be almost entirely restricted to nerve tissue. However, none of the cell lines used for NNV propagation has a nervous origin. In this study, first we established a protocol for the primary culture of neurons from Senegalese sole, which made it possible to further study virus-host cell interactions. Then, we compared the replication of three NNV strains with different genotypes (SJNNV, RGNNV and a RGNNV/SJNNV reassortant strain) in sole neuron primary cultures and E-11 cells. In addition, to study how two amino acid substitutions at the c-terminal of the capsid protein (positions 247 and 270) affect the binding to cell receptors, a recombinant strain was also tested. The results show that sole neural cells enabled replication of all the tested NNV strains. However, the recombinant strain shows a clearly delayed replication when compared with the wt strain. This delay was not observed in virus replicating in E-11 cells, suggesting a viral interaction with different cell receptors. The establishment of a sole primary neuronal culture protocol provides an important tool for research into betanodavirus infection in sole.
\end{abstract}

\section{Introduction}

Viral encephalopathy and retinopathy (VER), otherwise known as viral nervous necrosis (VNN), is a highly infective neuropathological condition that affects a wide range of fish species worldwide and causes mass mortalities, mainly in larval and juvenile stages [1]. The causative agents are Nervous necrosis viruses (NNV), small and non-enveloped viruses belonging to the G. Betanodavirus, F. Nodaviridae. The betanodavirus genome consists of two single stranded RNA molecules, RNA1 (3.1 Kb) and RNA2 $(1.4 \mathrm{~Kb})$, which encode the RNA-dependent RNA polymerase and the capsid protein, respectively [2]. A subgenomic transcript, known as RNA3, is synthesized during RNA replication from the $3^{\prime}$ terminus of RNA1. Betanodaviruses have been classified into four genotypes: striped jack nervous necrosis virus (SJNNV), tiger puffer nervous necrosis virus (TPNNV), redspotted grouper nervous necrosis virus (RGNNV) and barfin flounder

\footnotetext{
*Correspondence: sandra.souto@usc.es

Departamento de Microbiología y Parasitología, Instituto de Acuicultura,

Universidade de Santiago de Compostela, 15706 Santiago de

Compostela, Spain
}

nervous necrosis virus (BFNNV) [3], based on a small variable sequence of RNA2, the so-called T4 region. However, the isolation of reassortant strains between RGNNV and SJNNV genotypes has been reported from Senegalese sole (Solea senegalensis), gilthead sea bream (Sparus aurata) and sea bass (Dicentrarchus labrax) in southern Europe [4-7]. Reassortant strains isolated from diseased farmed Senegalese sole and gilthead sea bream in the Iberian Peninsula showed an RNA1 typed as RGNNV and an SJNNV-type RNA2 and exhibited a modified SJNNV capsid amino acid sequence [4]. We previously demonstrated that two of these modified positions (residues 247 and 270) play a major role in betanodavirus virulence for Senegalese sole, possibly due to a slower spread in fish brain tissue [8].

Betanodaviruses have a clear neurotropism [9] and their replication in the susceptible fish species seems to be almost entirely restricted to nerve tissue, preferentially the brain and retina $[10,11]$. Although different fish cell lines, including RTG-2, CHSE-214, BF2, SBL, FHM and EPC, have been tested for susceptibility to NNV [2, 12-15], the first successful isolation of a betanodavirus

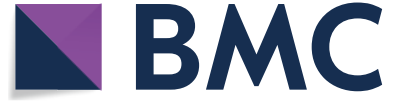

(c) The Author(s) 2018. This article is distributed under the terms of the Creative Commons Attribution 4.0 International License (http://creativecommons.org/licenses/by/4.0/), which permits unrestricted use, distribution, and reproduction in any medium, provided you give appropriate credit to the original author(s) and the source, provide a link to the Creative Commons license, and indicate if changes were made. The Creative Commons Public Domain Dedication waiver (http://creativecommons.org/ publicdomain/zero/1.0/) applies to the data made available in this article, unless otherwise stated. 
was achieved using the SSN-1 cell line, established from whole fry tissue of striped snakehead Ophicephalus striatus [16]. Subsequently, the GF-1 cell-line derived from grouper Epinephelus coioides, E-11, a clonal line derived from SSN-1 cells, and SB derived from Asian sea bass Lates calcarifer was also demonstrated to be useful for the isolation and proliferation of NNV [17-19]. It has been suggested that viral replication in these cell-lines and earlier failure in established cell lines may be due to the existence of a specific receptor for NNV [17]. However, none of these cell-lines has a neuronal origin and may not present specific receptors, such as the neural cell adhesion molecule (NCAM), a cell adhesion glycoprotein that in the rabies virus, a well-known neurotropic virus, plays a role in entry [20]. In the present study, we established a protocol to obtain primary neuron cultures from sole and analysed the effect of the two capsid mutations observed in the reassortant strains on viral replication in the neural cells.

\section{Materials and methods Experimental animals}

Senegalese sole $(20-50 \mathrm{~g})$ were obtained from commercial hatcheries and kept at the aquarium facilities of the University of Santiago de Compostela at $22{ }^{\circ} \mathrm{C}$. Upon arrival, some fish were sacrificed with an anaesthetic overdose (MS-222, tricaine methane sulphonate, Sigma) and used for diagnosis of bacterial pathogens as well as regular viral agents, including infectious pancreatic necrosis virus (IPNV), infectious haematopoietic necrosis virus (IHNV), viral haemorrhagic septicaemia virus (VHSV) and betanodavirus as described by [21]. All efforts were made to minimize the number of animals used and their suffering.

\section{Isolation of brain cells}

Senegalese sole were euthanized by an overdose of the anaesthetic MS-222. Fish were sprayed and wiped using $70 \%$ ethanol, and their brains were removed aseptically from the skull and immersed in Hank's buffer (Lonza) supplemented with $2 \mathrm{mM}$ glucose and $200 \mu \mathrm{g} / \mathrm{mL}$ gentamicin (dissection medium). Tissues were washed three times with the dissection medium and then placed in pools of 5 brains in a clean Petri dish with fresh medium and minced using a scalpel into smaller sections of 2-3 $\mathrm{mm}$. The primary culture of the isolated tissue was undertaken using enzymatic disaggregation by incubating the tissues in $6 \mathrm{~mL}$ of Neurobasal medium (Gibco) supplemented with $2 \mathrm{mM}$ glutamine (isolation medium) with a proteolytic enzyme. The first attempts to isolate neural cells were done using two different enzymes, papain and trypsin to assess their performance. Half of the tissue sample was incubated with a $20 \mathrm{U} / \mathrm{mL}$ papain solution (Sigma) for $30 \mathrm{~min}$ at $30{ }^{\circ} \mathrm{C}$ in a shaking water bath and the other half was incubated with $0.1 \%$ trypsin (Lonza) for $15 \mathrm{~min}$ at room temperature (RT). After allowing non-dispersed tissue to settle, the enzymes were removed and $2 \mathrm{~mL}$ of fresh medium were added. Then, the tissue was triturated with a flame-polished Pasteur pipette for $1 \mathrm{~min}$. After allowing non-triturated tissue to settle for $1 \mathrm{~min}$, the supernatant was transferred to an empty $15-\mathrm{mL}$ tube. This procedure was repeated twice combining all the supernatants from each sample. Subsequently, the cell suspension was carefully applied to the top of a prepared OptiPrep density gradient as described in [22]. The gradient was centrifuged at $800 \times g$ for $15 \mathrm{~min}$ at $22^{\circ} \mathrm{C}$. The top $6 \mathrm{~mL}$ containing cellular debris was discarded whereas three different fractions were collected separately; the top $1 \mathrm{~mL}$ of the gradient (Fraction 1), enriched for oligodendrocytes; the following $1 \mathrm{~mL}$ (Fraction 2) containing cell fragments, neurons and other cells, and the $2 \mathrm{~mL}$ at the bottom excluding the pellet (Fraction 3) enriched for neurons. Cell fractions 1 and 2 were discharged and fraction 3 was diluted with $10 \mathrm{~mL}$ isolation medium and centrifuged at $200 \times g$ for $2 \mathrm{~min}$ at $22{ }^{\circ} \mathrm{C}$. The supernatant was discarded and the cells were washed once more. The pellet was resuspended in $1 \mathrm{~mL}$ of the culture medium (see below) and the number of cells was estimated. Viability was tested using trypan blue dye exclusion. Cells were plated at a concentration of $2 \times 10^{5}$ cells $/ \mathrm{cm}^{2}$ in pre-coated $0.5 \mathrm{mg} / \mathrm{mL}$ poly-D-lysine (Sigma) 24-well plates for primary cultures (Sarstedt). Two different growth media were tested: Dulbecco's Modified Eagle Medium with Nutrient Mixture F-12 (DMEM/F12, Gibco) and Leibovitz's L-15 Medium. Both media supplemented with $1 \times$ B-27 (Gibco), 15\% FBS (Gibco), $2 \mathrm{mM}$ glutamine (Lonza), $15 \mathrm{ng} / \mathrm{mL}$ basic fibroblast growth factor (bFGF, Sigma) and $100 \mu \mathrm{g} / \mathrm{mL}$ gentamicin. After $24 \mathrm{~h}$, the media was partially removed and the wells were refilled with fresh culture media. To investigate the influence of temperature on cell proliferation, the sole brain cells were cultured at $15,20,25$ and $30{ }^{\circ} \mathrm{C}$. Cultures were examined daily and graded for confluency.

\section{Indirect immunolabeling}

Immunolabeling with a neuronal marker was used to identify neural cells. The medium from cells grown on coverslips was removed and cells were fixed for $20 \mathrm{~min}$ at $-20{ }^{\circ} \mathrm{C}$ in a solution of acetone:ethanol (1:1). Subsequently, the cells were washed three times for $5 \mathrm{~min}$ in PBS/Tween $0.05 \%$. The cells were incubated with the primary antibody against neurofilaments (NF-200, Sigma) at room temperature (RT) for $1 \mathrm{~h}$ and washed three times in PBS/Tween $0.05 \%$. The coverslips were then treated with FITC-conjugated anti-mouse immunoglobulins (Sigma) in $\mathrm{PBS} /$ Tween $0.05 \%$ for $1 \mathrm{~h}$ at RT in the dark. Then 
they were washed again three times for 5 min in PBS/ Tween $0.05 \%$ and stained with DAPI (Sigma) according to the manufacturer's instructions. Immunofluorescencelabelled cells were analysed using a Nikon fluorescence microscope.

\section{Betanodavirus replication in sole brain cells Viruses, cells, and virus growth}

The betanodavirus strains used in this study were the following: SGWak97 and SJNag93 belonging to the RGNNV and SJNNV genotypes, respectively [23] SpSsIAusc160.03, a reassortant RGNNV/SJNNV strain isolated from diseased farmed sole [4], hereafter wild-type strain or wt160 and the recombinant strains rSs 160.03 and $\mathrm{rSs} 160_{247+270}$ previously described in detail [8], hereafter $\mathrm{r} 160$ and $\mathrm{r} 247+270$, respectively. These two recombinant strains have been produced by reverse genetics; r160 has a genome sequence identical to wt160, whereas $r 247+270$ bear two amino acid substitutions at the C-terminal of the coat protein and has lower in vivo fitness than wt160 [8]. The viruses were maintained and propagated in E-11 cells [17] with L-15 medium containing $2 \%$ foetal bovine serum (FBS), penicillin (100 IU/ $\mathrm{mL})$ and streptomycin $(100 \mu \mathrm{g} / \mathrm{mL})$ at $25{ }^{\circ} \mathrm{C}$ and stored at $-80{ }^{\circ} \mathrm{C}$, as previously described [8]. Viral strains were titrated in triplicate by the endpoint dilution method on 96-well plates. The $\mathrm{TCID}_{50} / \mathrm{mL}$ (tissue-culture infectious dose infecting $50 \%$ of inoculated cultures) was calculated according to the method described in [24].

\section{Infection of brain cells with betanodavirus}

Three well plates containing sole brain cells ( $70 \%$ confluence) approximately 15 days post-seeding were infected with either wt160, recombinant viruses, SGWak97 or SJNag93, at a M.O.I of 0.01. After $1 \mathrm{~h}$ adsorption, the virus was removed and $1 \mathrm{~mL}$ of fresh medium L-15 supplemented with $1 \times$ B-27 (Gibco), 2\% FBS (Gibco), $2 \mathrm{mM}$ glutamine (Lonza) and $100 \mu \mathrm{g} / \mathrm{mL}$ gentamicin was added and incubated at $25{ }^{\circ} \mathrm{C}$. Three non-infected wells per plate were used as negative controls. Samples from supernatant $(0.1 \mathrm{~mL})$ were collected at various times post-infection (pi): 1, 5, 7, 9, 11 and 12 days postinfection (dpi) and an equal amount of fresh medium was subsequently added to the wells at each time point. Virus yields were determined by RT-qPCR.

\section{Infection of E-11 cells with betanodavirus}

Three well plates containing E-11 cells were infected with the same strains described above at an M.O.I of 0.01 . After $1 \mathrm{~h}$ adsorption, the virus was removed and $1 \mathrm{~mL}$ of fresh medium L-15 supplemented with $2 \%$ foetal bovine serum (FBS), penicillin (100 IU/mL) and streptomycin $(100 \mu \mathrm{g} / \mathrm{mL})$ was added and incubated at $25{ }^{\circ} \mathrm{C}$. Samples from supernatant were collected at: 1, 3, 5 and $6 \mathrm{dpi}$ and subjected to RT-qPCR.

\section{Virus quantification by RT-qPCR}

RNA was extracted from $0.1 \mathrm{~mL}$ of the cell supernatants using the EZNA Total RNA kit (Omega Bio-tek), according to the manufacturer's instructions. The total RNA collected was suspended in $50 \mu \mathrm{L}$ molecular-grade water and stored at $-80{ }^{\circ} \mathrm{C}$. cDNA synthesis was performed by mixing RNA with random primers, heating at $95^{\circ} \mathrm{C}$ for $5 \mathrm{~min}$ and incubating at $4{ }^{\circ} \mathrm{C}$ for at least $1 \mathrm{~min}$. Then, a reverse transcription mixture containing Superscript III RT (Invitrogen) was added and incubated at $25{ }^{\circ} \mathrm{C}$ for $10 \mathrm{~min}$. RT reactions were performed at $50{ }^{\circ} \mathrm{C}$ for $50 \mathrm{~min}$, followed by $5 \mathrm{~min}$ at $85^{\circ} \mathrm{C}$ for RT enzyme inactivation. The cDNA was then added into real-time PCR buffer, which included $0.2 \mathrm{mM}$ forward and reverse primers SnodR1 [21] in 1× NZYTaq Green Master Mix (NZYTech). The quantitative PCR was carried out using the CFX96TM Real-Time PCR Detection System (Bio$\mathrm{Rad}$ ) as previously described [8] with a thermocycling program consisting of an initial denaturation/activation step at $95{ }^{\circ} \mathrm{C}$ for $15 \mathrm{~min}$, and 40 cycles of amplification (denaturation at $95{ }^{\circ} \mathrm{C}$ for $15 \mathrm{~s}$, annealing and extension at $60{ }^{\circ} \mathrm{C}$ for $15 \mathrm{~s}$ ). To prepare the standard curve, 20 -fold dilutions of a plasmid containing the full-length RNA1 of strain SpSs-IAusc160.03 were prepared. Viral load data were calculated as RNA1 copies per mL of supernatant. All samples were tested in triplicate.

\section{Statistics}

Statistical analyses of all data were performed using GraphPad Prism 5.0. All results obtained from quantitative RT-PCR were expressed as mean \pm SD. Data were tested for significance by analysis of variance (two-way Anova), followed by Bonferroni post hoc tests to determine differences among the obtained virus concentrations. Mean values were considered significant when $p<0.05$.

\section{Results}

The first aim of this study was to establish the optimal conditions for primary cell culture from the brain tissue of Senegalese sole and subsequently test their susceptibility to betanodavirus infection.

\section{Optimal culture conditions establishment}

The isolation and culture of the brain cells was carried out following the protocol described by [22] for the isolation of neurons and neurospheres from adult rats or mice with some modifications. Different conditions were tested in order to obtain the most suitable protocol for the sole neuron culture development and maintenance. 
Initial investigations into the best method to disaggregate tissue demonstrated that papain digestion resulted in a higher yield of cells than trypsin. Digestion using papain led to a complete disaggregation of the tissue, a higher viability of the harvested cells and also a better cell attachment after seeding.

The OptiPrep density gradient made it possible to isolate purer cell fractions, reducing the presence of cellular debris and blood cells. Three different fractions were initially used to produce the primary cultures. Neuron and neurosphere development was higher when using fraction 3 compared to fractions 1 and 2 , as indicated by the immunolabeling of the anti-neurofilament neuronal marker. Therefore, this fraction was used for all subsequent experiments.

To determine the more suitable temperature conditions after the isolation protocol, neural cells were incubated at $15,20,25$ and $30{ }^{\circ} \mathrm{C}$. Survival and confluency varied depending on temperature. The lowest viability was obtained at 15 and $30{ }^{\circ} \mathrm{C}$. Poor attachment of the cells and a low rate of cellular differentiation were observed at $15{ }^{\circ} \mathrm{C}$, while at $30^{\circ} \mathrm{C}$ cells were able to attach at the beginning and axons began to develop but then necrotic cells appeared after 4-6 days and most of the cell layer was detached from the well surface by days $7-8$ post-seeding. The best cellular adhesion and cell differentiation was observed at 20 and $25^{\circ} \mathrm{C}$; even though the best temperature for growing was determined to be $25^{\circ} \mathrm{C}$, because at this temperature the cultures developed a more complex neuronal network.

The cultivation of cells in L-15 medium resulted in an increased survival of cells and neurite differentiation after seeding. L-15 enhanced neurons developed branching neurites forming a neuronal network, whereas wells cultured with DMEM/F12 show more proliferation of glial cells and nonneuronal cell types, such as fibroblasts. Moreover, after $2-3$ days at $25{ }^{\circ} \mathrm{C}$ and without supplementation of exogenous $\mathrm{CO}_{2}$, the DMEM/F12 medium was not able to maintain the optimal $\mathrm{pH}$ conditions, becoming too basic and causing detrimental effects on the cells. Hence, L-15 medium was selected for further experiments.

After $24 \mathrm{~h}$, primary cultures, obtained with the optimum conditions described above, show cells with a spherical morphology (Figure 1A). By days 4-5, numerous bright cell aggregates with a spherical shape that did not attach to the well surface and that were identified as neurospheres, were observed (Figure 1B). Then, between days 5 and 15 post-seeding cells began to attach and proliferate, neurite-like fibers grew and contacted with neighbouring aggregates (Figure 1C). Immunocytochemical staining showed that the cells were marked with the
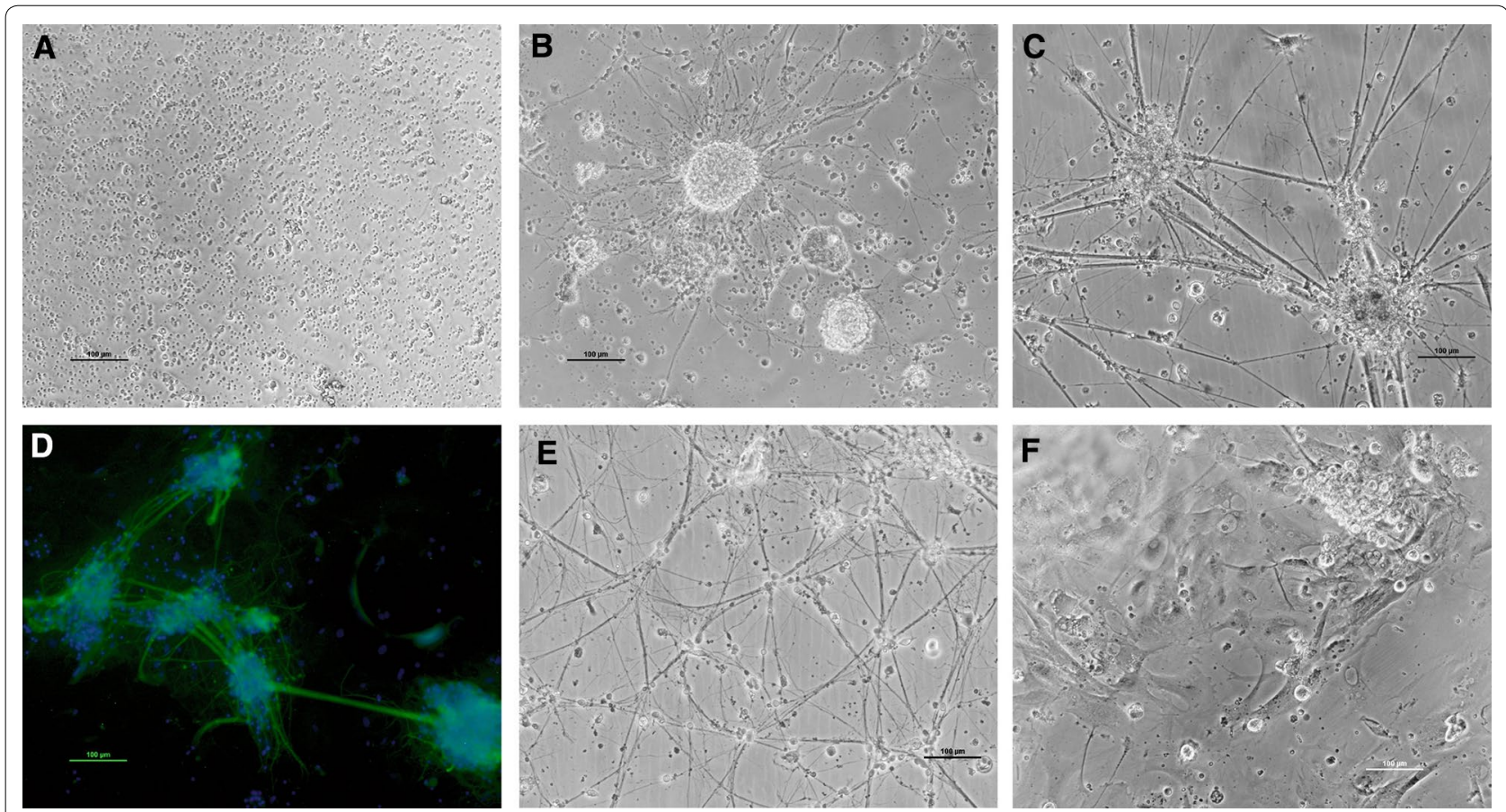

Figure 1 Primary sole neuronal cultures. A Spherical cells after 24 h, B cell aggregates, C neuronal connections, D immunofluorescent staining with the neurofilament specific antibody (NF-200), $\mathbf{E}$ differentiated cells after 15 days in culture, $\mathbf{F}$ differentiated cells after 30 days in culture. Scale bar $100 \mu \mathrm{m}$. 
neuron specific antibody NF-200 (Figure 1D). In addition, different types of cells proliferated to form a layer of adherent cells that developed to reach confluence under the neural cells. At day 15, the cultures reached the maximum neurite development (Figure 1E). Healthy primary cultures could be maintained for approximately 1 month (Figure 1F).

\section{Infection of brain cells with betanodavirus}

The replication in the neuron primary cultures of NNV strains belonging to different genotypes, including the recombinant strain $\mathrm{r} 247+270$, was evaluated by realtime qPCR. No virus was detected in the non- infected

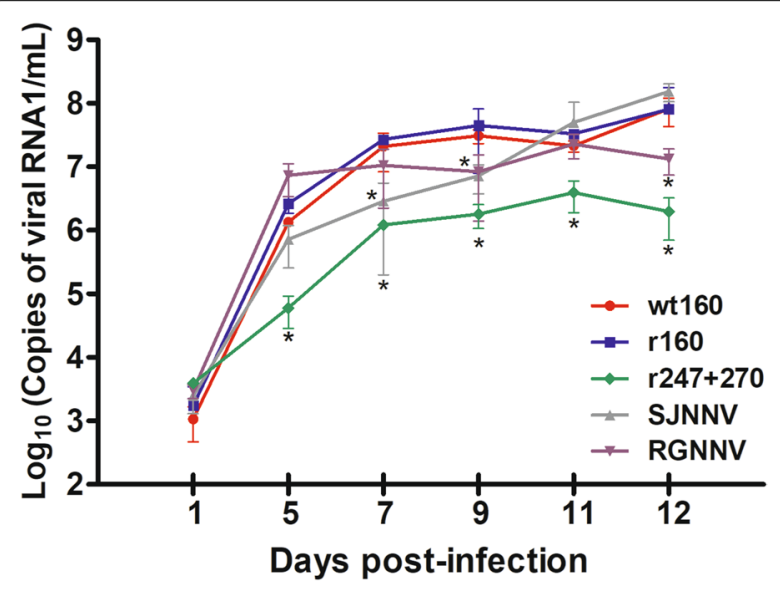

Figure 2 Viral replication in brain cells from primary cultures. Samples were analysed by RNA1 quantification by RT-qPCR per $\mathrm{mL}$ of supernatant. Means and standard deviations from three wells are presented. ${ }^{*} p<0.05$ for differences with the wild type virus (wt160). wells. All strains were able to enter cells and replicate; at day 1 pi all strains displayed a similar RNA1 load $\left(1.1-3.9 \times 10^{3}\right.$ copies $/ \mathrm{mL}$ ) (Figure 2). The highest viral replication at $5 \mathrm{dpi}$ was observed with the RGNNV strain SGwak97 $\left(7.3 \times 10^{6}\right.$ copies $\left./ \mathrm{mL}\right)$, the replication of this strain increased until day 9 but then reached a plateau. The SJNNV strain showed a different behaviour, a slow load increase from 5 to $9 \mathrm{dpi}$ and a higher increase afterwards. Both, the wt160 and r160 strains show very similar replication kinetics, with a continuous increase throughout the whole experimental period and reaching maximum values of $8 \times 10^{8}$ copies $/ \mathrm{mL}$ at $12 \mathrm{dpi}$. When compared with the reassortant strain, SJNag93 and SGwak97 show a significant replication delay at days 7 and 9, respectively. Thereafter, the SJNNV strain reached values similar to those of the reassortant strain, whereas the RGNNV strain had a significantly lower RNA1 load $(p<0.05)$. It is interesting to note that the genomic load was significantly lower in $\mathrm{r} 247+270$ than in the wild type strain or $\mathrm{r} 160$. Sequence analysis of PCR products confirmed that mutations were maintained during replication in neural cells. Cell destruction $(80-100 \%)$ was observed by day $12 \mathrm{pi}$ in all the infected wells (Figure $3 \mathrm{~A}$ ), which were clearly differentiated from control cells (Figure 3B). Wells inoculated with the r $247+270$ strain presented a reduction in the severity of the cytopathic effect (CPE).

\section{Infection of E-11 cells with betanodavirus}

In the in vitro infection using E-11 cells, very similar replication kinetics were observed between the different strains (Figure 4). Although at day 3 pi the RNA1 copy number of SGWak97 was nearly 1 log higher than that
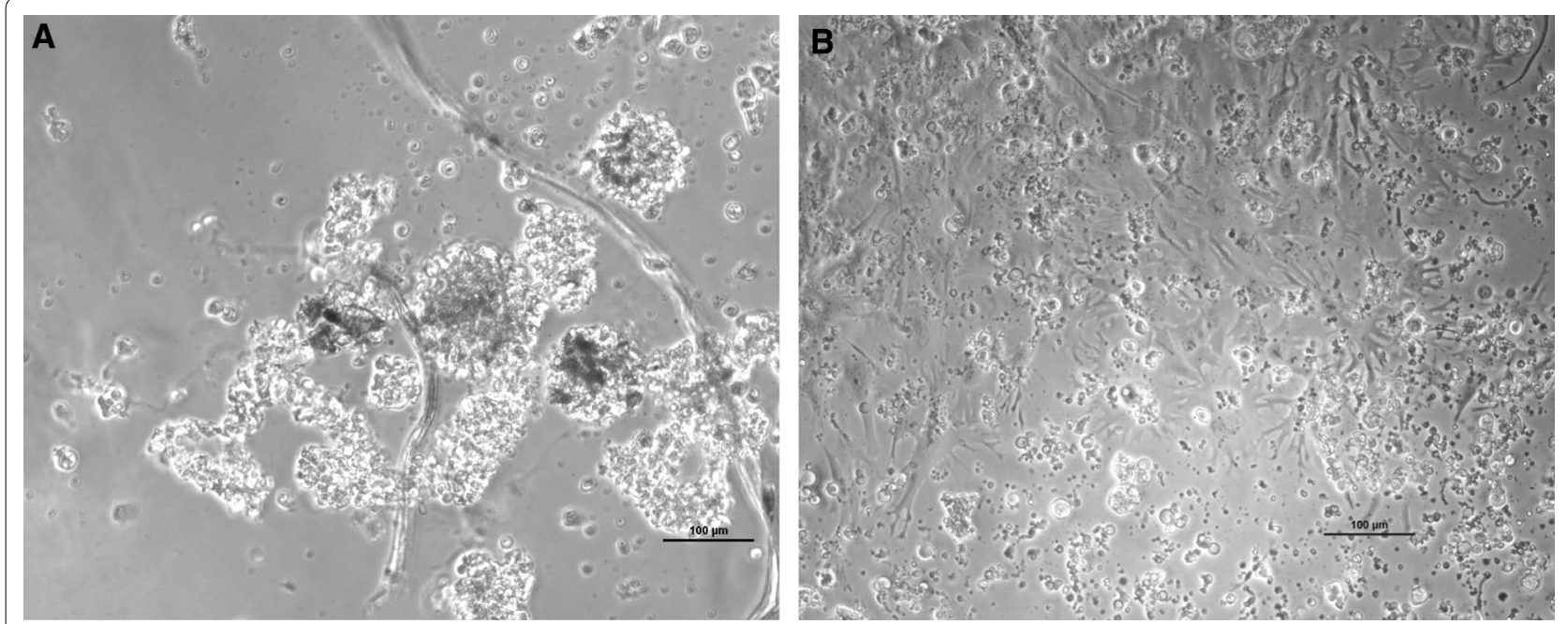

Figure 3 Primary sole neuronal cultures after $\mathbf{2 8}$ days in culture. A CPE at 12 dpi with wt 160, B control uninfected cells. 


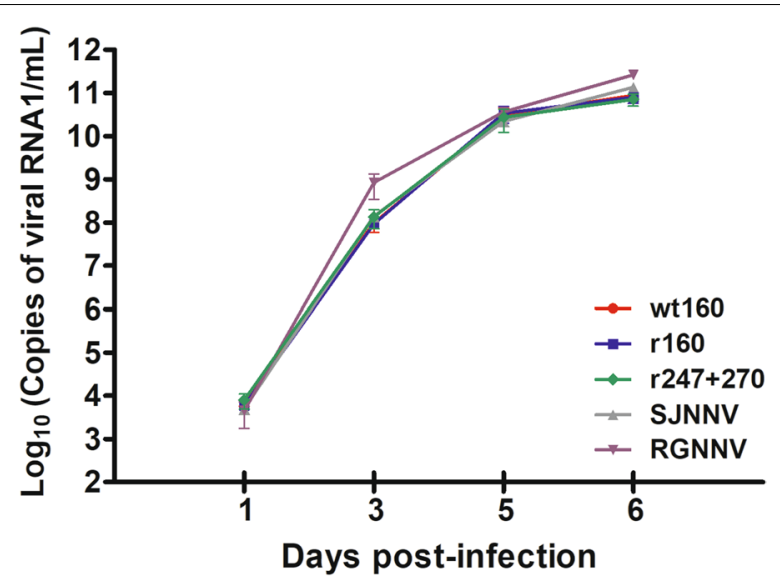

Figure 4 Viral replication in E-11 cells. Data are expressed as viral RNA1 detected in E-11 cell supernatants. Means and standard deviations from three wells are presented.

of the reassortant strain, afterwards no significant differences were observed between the strains and they both reached very similar values at the end of the experiment (6 dpi when complete destruction of the cell monolayers was observed). Viral production in E-11 was 3 logs higher than in neurons for reassortant strain (wt and r160) and SJNag93, and 4 logs higher for SGwak97 and r247 + 270 .

\section{Discussion}

Betanodavirus replication in fish shows a marked preference for neurological tissues, mainly the brain and retina. We previously reported that reassortant strains RGNNV/ SJNNV isolated from sole show two amino acid substitutions in the capsid protein with respect to the SJNNV capsid [4]. These substitutions seem to delay the virus spreading in sole brain tissue but do not affect viral replication in E-11 cells [8]. This different replication behaviour in vivo and in vitro prompted us to look for a neural cell culture to confirm the effect of capsid substitutions in betanodavirus replication in its target cells, namely neurons. However, although the establishment of a culture of stem neural cells from sea bass has been reported [25], due to technical problems and contamination, as indicated by the authors, these cells are not available to the scientific community. Therefore, in this study we established a protocol for isolation and primary culture of sole neurons and we assessed the replication of different NNV strains in these cells. In addition, we comparatively analysed the effect of capsid mutation on betanodavirus replication in the neural cells and the E-11 cell line.

Adult neurogenesis is a phenomenon found in the brain of all vertebrates studied to date. In teleost fish, neurons are produced in all brain subdivisions [26]. Different protocols have been published to obtain brain cells from different fish species [25, 27-31] and the most used enzymes to digest tissue samples are papain and trypsin. Therefore, to develop the sole neurons isolation protocol we evaluated the dispersion capacity of both enzymes. Papain treatment yielded the best results because a higher number of dissociated viable cells was obtained. In addition, these cells were better than those treated with trypsin in terms of development and attachment to the plate surface. These results concur with those obtained from the isolation of neurons from the tropical freshwater fish species Hoplias malabaricus [31]. As media composition and temperature have been reported to affect the growth of different brain cells [25, 29, 30, 32], the influence of both factors on sole neuron development was investigated. When DMEM/F12 was used, most new cells differentiated into glial cells, which almost covered all the plate surface, and few neurospheres and neurons were observed, thus the final neuron count was quite low. However, when L-15 was used, a proper neuronal network was set up achieving maximal growth at 15 days and healthy monolayers were maintained up to 30-35 days. Different results have been reported on the usefulness of each media to support brain cell grown. Whereas L-15 has also been successfully used for culturing neural stem cells from sea bass [30] or astrocytes from rainbow trout [29], DMEM/F12 has been reported to provide excellent results for the isolation of neurons from the tropical fish species $H$. malabaricus [31], Apteronotus leptorhynchus [25] and Astatotilapia burtoni [33]. Although four different growth temperatures were assayed, only two proved to be appropriate for sole neuron development. Low $\left(15^{\circ} \mathrm{C}\right)$ temperatures did not support the growth of sole brain cells, although this fish species can be found in the wild between 13 and $28{ }^{\circ} \mathrm{C}$ [34]. Temperatures lower than $20^{\circ} \mathrm{C}$ have also been reported to be inadequate for rainbow trout astrocyte culture [29]. High temperatures $\left(30{ }^{\circ} \mathrm{C}\right)$ did not allow successful growth either. However, at $20{ }^{\circ} \mathrm{C}$ and $25^{\circ} \mathrm{C}$ a high number of neurospheres was obtained and good cellular adhesion and cell differentiation was observed; $25{ }^{\circ} \mathrm{C}$ was considered the best temperature because cell cultures developed a more complex neuronal network. Temperatures higher than $20{ }^{\circ} \mathrm{C}$ have also been chosen to culture sea bass neurons [30].

All five NNV strains were replicated in the sole neural cells and displayed a similar genomic load at day 1 pi. However, afterwards, the recombinant strain harbouring substitutions at positions 247 and 270 in the capsid protein showed a clearly delayed replication when compared with wt160 and r160. Both amino acids are located on the outer surface of the capsid $[35,36]$ and therefore may be involved in the interaction with the host cell surface. We previously postulated that these amino acidic changes may modify the affinity of virus for cellular receptors 
and affect its spread through sole brain [8] and the marked replication delay of the recombinant throughout our experiments supports this hypothesis. As previously reported, a single mutation in the capsid affects the alphavirus Sindbis virus binding to and spreading through neural cells [37]. It is interesting to note that the point mutations performed on $\mathrm{r} 247+270$ reverted the substitutions observed in the reassortant strains back to the SJNNV-type; but although SJNag93 (the SJNNV strain used in this study) showed a replication delay from days 5 to 9 with respect to the wt and r160 strains, thereafter it reached similar RNA values. This result indicates that other factors besides these capsid amino acids must be involved in the delayed replication of $\mathrm{r} 247+270$. Although changes in positions 247 and 270 are shared by all reassortant strains isolated in the Iberian Peninsula [4], the wt 160 strain shows three additional differences in the coat protein sequence from the SJNag93 strain, at positions 13, 20 and 79. These three changes are not in the C-terminal side of the coat protein and therefore it is not probable that they are involved in host cell interaction. However, we observed that the substitution of amino acid 20 causes a delay in the viral replication in the brain tissue of experimentally infected fish, which is increased if fish are infected with mutant harbouring substitutions at positions 20, 247 and 270 (unpublished results). Experiments are in progress to study the effect of all capsid substitutions on the reassortant replication in neural primary cultures.

On the contrary, the experiments of replication in E-11 cells, shorter in time than experiments with neural cells because of the viral destruction of the monolayers, showed almost identical results for all 5 strains, and no delay of the mutant strain was observed. In addition, a higher viral production than in neural cells was obtained, although this could be due to the different number of cells present in each culture. The different replication behaviour of $\mathrm{r} 247+270$ in both E-11 and sole neurons could be explained by an interaction with different cell receptors. Sialic acid seems to be involved in the binding of betanodavirus to $\mathrm{SNN}-1$ cells [38] and therefore also to E-11, which are a clone of SSN-1 [17]. However, in other cell lines, other NNV receptors have been identified. Thus, in GF-1 grouper heat shock cognate protein 70 (GHSC70) has been proposed as an NNV receptor or co-receptor protein [39] and in SB cells receptors have been reported to probably be proteins located at lipid rafts or even specific lipids [40]. Although so far no data regarding the neuronal receptors involved in NNV entry is available, it is quite probable that neuronal receptors are different to those present in these cell lines, because two of them, SSN-1 and SB were derived from whole fry or larvae tissue [16, 41] and GF-1 from fin tissue [18]. In other viruses, like rabies viruses, it has been reported that most of the fixed rabies virus laboratory strains have acquired the ability to use ubiquitous receptors present at the surface of non-neuronal cell types, which are different from the neuronal receptors used to propagate in the nervous system [42].

In conclusion, although we have not been able to establish a long-term culture of sole neural cells, we have obtained primary cultures that lasted for a month and enable betanodavirus replication. NNV replication in neurons pointed out the existence of cell-receptors different to those characterized in E-11 cells, and probably in other cell lines.

\section{Abbreviations}

NNV: nervous necrosis virus; SJNNV: striped jack nervous necrosis virus; RGNNV: redspotted grouper nervous necrosis virus; RTG-2: rainbow trout gonad cells; CHSE-214: Chinook salmon embryo cells; BF2: blue gill fibroblast cells; SBL: sea bass larvae cells; FHM: fathead minnow cells; EPC: epithelioma papulosum cyprini cells; SSN-1: striped snakehead cells; GF-1: grouper fin cells; SB: Asian sea bass fibroblast cells larvae; NCAM: neural cell adhesion molecule; bFGF: basic fibroblast growth factor; M.O.I: multiplicity of infection; NCR: non coding regions; pi: post-infection; CPE: cytopathic effect.

\section{Competing interests}

The authors declare that they have no competing interests.

\section{Authors' contributions}

IB, SS conceived and designed the experiments. SS, LVS, JGO performed the experiments. IB, SS, JGO, CPD analysed the data. SS, IB wrote the paper. CPD revised the paper. All authors read and approved the final manuscript.

\section{Acknowledgements}

The authors would like to thank Lorena Martinez, Carmen López-Vazquez, Alicia Ana Silva and Johnny Franqueira, for their contribution to this work, and John Souto for the English revision. The authors also thank Stolt Sea Farm S.A. (Galicia, Spain) for kindly providing the fish used in this study.

\section{Ethics approval and consent to participate}

Fish used in this work were handled in strict accordance with good animal practices as defined by the European Union guidelines for the handling of laboratory animals (Directive 2010/63/UE). The protocol was approved by the Galician Committee for experimental animal's welfare and the Xunta de Galicia (Permit Id. 15004/13/002).

\section{Funding}

This work was supported by Grant AGL2014-54532-C2-2-R from the Ministerio the Innovación y Competitividad (Spain), cofunded by FEDER.

\section{Publisher's Note}

Springer Nature remains neutral with regard to jurisdictional claims in published maps and institutional affiliations.

Received: 6 June 2018 Accepted: 4 July 2018

Published online: 05 September 2018

\section{References}

1. Doan QK, Vandeputte M, Chatain B, Morin T, Allal F (2017) Viral encephalopathy and retinopathy in aquaculture: a review. J Fish Dis 40:717-742

2. Mori K, Nakai T, Muroga K, Arimoto M, Mushiake K, Furusawa I (1992) Properties of a new virus belonging to nodaviridae found in larval striped jack (Pseudocaranx dentex) with nervous necrosis. Virology 187:368-371 
3. Nishizawa T, Furuhashi M, Nagai T, Nakai T, Muroga K (1997) Genomic classification of fish nodaviruses by molecular phylogenetic analysis of the coat protein gene. Appl Environ Microbiol 63:1633-1636

4. Olveira JG, Souto S, Dopazo CP, Thiéry R, Barja JL, Bandín I (2009) Comparative analysis of both genomic segments of betanodaviruses isolated from epizootic outbreaks in farmed fish species provides evidence for genetic reassortment. J Gen Virol 90:2940-2951

5. Panzarin V, Fusaro A, Monne I, Cappellozza E, Patarnello P, Bovo G, Capua I, Holmes EC, Cattoli G (2012) Molecular epidemiology and evolutionary dynamics of betanodavirus in southern Europe. Infect Genet Evol 12:63-70

6. Toffolo V, Negrisolo E, Maltese C, Bovo G, Belvedere P, Colombo L, Dalla Valle $L$ (2007) Phylogeny of betanodaviruses and molecular evolution of their RNA polymerase and coat proteins. Mol Phylogenet Evol 43:298-308

7. Toffan A, Pascoli F, Pretto T, Panzarin V, Abbadi M, Buratin A, Quartesan R, Gijón D, Padrós F (2017) Viral nervous necrosis in gilthead sea bream (Sparus aurata) caused by reassortant betanodavirus RGNNV/SJNNV: an emerging threat for Mediterranean aquaculture. Sci Rep 7:46755

8. Souto S, Mérour E, Biacchesi S, Brémont M, Olveira JG, Bandín I (2015) In vitro and in vivo characterization of molecular determinants of virulence in reassortant betanodavirus. J Gen Virol 96:1287-1296

9. Munday BL, Kwang J, Moody N (2002) Betanodavirus infections of teleost fish: a review. J Fish Dis 25:127-142

10. Nguyen HD, Nakai T, Muroga K (1996) Progression of striped jack nervous necrosis virus (SJNNV) infection in naturally and experimentally infected striped jack Pseudocaranx dentex larvae. Dis Aquat Organ 24:99-105

11. Skliris $G$, Richards R (1999) Induction of nodavirus disease in seabass, Dicentrarchus labrax, using different infection models. Virus Res 63:85-93

12. Breuil G, Bonami JR, Pepin JF, Pichot Y (1991) Viral infection (picornalike virus) associated with mass mortalities in hatchery-reared sea-bass (Dicentrarchus labrax) larvae and juveniles. Aquaculture 97:109-116

13. Munday BL, Langdon JS, Hyatt A, Humphrey JD (1992) Mass mortality associated with a viral-induced vacuolating encephalopathy and retinopathy of larval and juvenile barramundi, Lates calcarifer Bloch. Aquaculture 103:197-211

14. Fukuda Y, Nguyen H, Furuhashi M, T Nakai (1996) Mass mortality of cultured sevenband grouper, Epinepheulus septemfasciatus, associated with viral nervous necrosis. Fish Pathol 31:165-170

15. Delsert C, Morin N, Comps M (1997) Fish nodavirus lytic cycle and semipermissive expression in mammalian and fish cell cultures. J Virol 71:5673-5677

16. Frerichs GN, Rodger HD, Peric Z (1996) Cell culture isolation of piscine neuropathy nodavirus from juvenile sea bass, Dicentrarchus labrax. J Gen Virol 77:2067-2271

17. Iwamoto T, Nakai T, Mori K, Arimoto M, Furusawa I (2000) Cloning of the fish cell line SSN-1 for piscine nodaviruses. Dis Aquat Organ 43:81-89

18. Chi SC, Hu WW, Lo BJ (1999) Establishment and characterization of a continuous cell line (GF-1) derived from grouper, Epinephelus coioides (Hamilton): a cell line susceptible to grouper nervous necrosis virus (GNNV). J Fish Dis 22:173-182

19. Tan C, Huang B, Chang SF, Ngoh GH, Munday B, Chen SC, Kwang J (2001) Determination of the complete nucleotide sequences of RNA1 and RNA2 from greasy grouper (Epinephelus tauvina) nervous necrosis virus, Singapore strain. J Gen Virol 82:647-653

20. Lafon M (2005) Rabies virus receptors. J Neurovirol 11:82-87

21. Olveira JG, Souto S, Dopazo CP, Bandín I (2013) Isolation of betanodavirus from farmed turbot Psetta maxima showing no signs of viral encephalopathy and retinopathy. Aquaculture 406:125-130

22. Brewer GJ, Torricelli JR (2007) Isolation and culture of adult neurons and neurospheres. Nat Protoc 2:1490-1498
23. Iwamoto T, Mori K, Arimoto M, Nakai T (1999) High permissivity of the fish cell line SSN-1 for piscine nodaviruses. Dis Aquat Organ 39:37-47

24. Reed $L$, Müench $H$ (1938) A simple method of estimating fifty per cent endpoints. Am J Epidemiol 27:493-497

25. Hinsch K, Zupanc GKH (2006) Isolation, cultivation, and differentiation of neural stem cells from adult fish brain. J Neurosci Methods 158:75-88

26. Chapouton P, Jagasia R, Bally-Cuif L (2007) Adult neurogenesis in nonmammalian vertebrates. BioEssays 29:745-757

27. Ghosh C, Liu Y, Ma C, Collodi P (1997) Cell cultures derived from early zebrafish embryos differentiate in vitro into neurons and astrocytes. Cytotechnology 23:221-230

28. Andersen S (2001) Preparation of dissociated zebrafish spinal neuron cultures. Methods Cell Sci 23:205-2209

29. Fröjdö EM, Westerlund J, Isomaa B (2002) Culturing and characterization of astrocytes isolated from juvenile rainbow trout (Oncorhynchus mykiss). Comp Biochem Physiol A 133:17-28

30. Servili A, Bufalino MR, Nishikawa R, Sanchez de Melo I, Muñoz-Cueto JA, Lee LEJ (2009) Establishment of long term cultures of neural stem cells from adult sea bass, Dicentrarchus labrax. Comp Biochem Physiol A 152:245-254

31. da Silva CA, de Morais EC, Costa MD, Ribas JL, Guiloski IC, RamsdorfWA, Zanata SM, Cestari MM, Ribeiro CA, Magalhães VF, Trudeau VL, de Assis HC (2014) Saxitoxins induce cytotoxicity, genotoxicity and oxidative stress in teleost neurons in vitro. Toxicon 86:8-15

32. Kaiser $\mathrm{O}$, Aliuos P, Wissel K, Lenarz T, Werner D, Reuter G, Kral A, Warnecke A (2013) Dissociated neurons and glial cells derived from rat inferior colliculi after digestion with papain. PLoS One 8:e80490

33. Mack AF, Tiedemann K (2013) Cultures of astroglial cells derived from brain of adult cichlid fish. J Neurosci Methods 212:269-275

34. Vinagre C, Fonseca V, Cabral H, Costa MJ (2006) Habitat suitability index models for the juvenile soles, Solea solea and Solea senegalensis, in the Tagus estuary: defining variables for species management. Fish Res 82:140-149

35. Tang L, Lin C-S, Krishna NK, Yeager M, Schneemann A, Johnson JE (2002) Virus-like particles of a fish nodavirus display a capsid subunit domain organization different from that of insect nodaviruses. J Virol 76:6370-6375

36. Chen NC, Yoshimura M, Guan HH, Wang TY, Misumi Y, Lin CC, Chuankhayan P, Nakagawa A, Chan SI, Tsukihara T, Chen TY, Chen CJ (2015) Crystal structures of a piscine betanodavirus: mechanisms of capsid assembly and viral infection. PLoS Pathog 11:e1005203

37. Lee P, Knight R, Smit JM, Wilschut J, Griffin DE (2002) A single mutation in the E2 glycoprotein important for neurovirulence influences binding of sindbis virus to neuroblastoma cells. J Virol 76:6302-6310

38. Liu W, Hsu C-H, Hong Y-R, Wu S-C, Wang C-H, Wu Y-M, Chao C-B, Lin C-S (2005) Early endocytosis pathways in SSN-1 cells infected by dragon grouper nervous necrosis virus. J Gen Virol 86:2553-2561

39. Chang J-S, Chi S-C (2015) GHSC70 is involved in the cellular entry of nervous necrosis virus (NNV). J Virol 89:61-70

40. Huang R, Zhu G, Zhang J, Lai Y, Xu Y, He J, Xie J (2018) Betanodavirus-like particles enter host cells via clathrin-mediated endocytosis in a cholesterol-, pH- and cytoskeleton-dependent manner. Vet Res 48:8

41. Chew-Lim M, Chong SY, Yoshimizu M (1998) A Nodavirus isolated from grouper (Epinephelus tauvina) and seabass (Lates calcarifer). Fish Pathol 33:447-448

42. Seganti L, Superti F, Bianchi S, Orsi N, Divizia M, Panà A (1990) Susceptibility of mammalian, avian, fish, and mosquito cell lines to rabies virus infection. Acta Virol 34:155-163 